\title{
Inequality of Educational Opportunity in East and West Germany: Convergence or Continued Differences?
}

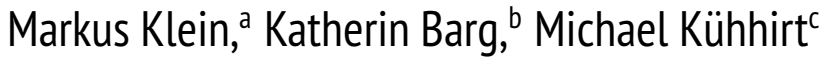 \\ a) University of Strathclyde; b) University of Exeter; c) University of Cologne
}

Abstract: Diversity in education systems, and broader political and economic conditions, are commonly credited with international variation in inequality of educational opportunity (IEO). Comparing East and West Germany before reunification allows us to investigate whether vastly different political, economic, and educational systems led to differences in IEO. Postreunification, East Germany adopted the West's systems and experienced an economic recession. IEO had been smaller in East Germany than in West Germany but was on an upward trajectory before reunification. After 1990, IEO in East Germany converged to the West German level as a result of decreased IEO in the west and increasing levels in the east. Postreunification convergence suggests that differences in political context and education policy are crucial for IEO.

Keywords: educational inequality; education policy; comparative research; educational reforms; education systems; German reunification

Citation: Klein, Markus, Katherin Barg, and Michael Kühhirt. 2018. "Inequality of Educational Opportunity in East and West Germany: Convergence or Continued Differences?" Sociological Science 6: 1-26.

Received: October 15, 2018

Accepted: November 21, 2018

Published: January 10, 2019

Editor(s): Jesper Sørensen, Stephen Morgan

Dol: $10.15195 /$ v6.a1

Copyright: @ 2019 The Author(s). This open-access article has been published under a Creative Commons Attribution License, which allows unrestricted use, distribution and reproduction, in any form, as long as the original author and source have been credited. (C) (i)
TEQUALITY of educational opportunity (IEO) — that is, the association between 1 individuals' chances of attaining education and their ascribed characteristics, such as sex, race, or class-is an important indicator of a society's openness. Several studies found substantial differences in the degree of IEO by social origin between countries (Blossfeld and Shavit 1993; Breen et al. 2009; Pfeffer 2008). These differences are linked to institutional features within national education systems, such as early segregation into different educational tracks and levels of standardization in curricula, assessments, and schooling (e.g., Bol et al. 2014; Brunello and Checchi 2007; Hanushek and Wößmann 2006; Pfeffer 2015). The more "stratified" and less "standardized" the education system regarding school-leaving examinations, teachers' training, school budgets, and curricula, the larger the IEO (van de Werfhorst and Mijs 2010).

IEO by social origin may also vary according to macro-level political and socioeconomic conditions facing students and their parents. As economic development and technical progress require the more efficient use of talent, free-market economies may inevitably develop toward selection based on merit (Kerr et al. 1973; Treiman 1970). In contrast, Bukodi and Goldthorpe (2010) argue that free-market economies are incompatible with an education-based meritocracy because individuals of higher social backgrounds can convert parental resources into educational advancements. They argue that policies employed by formerly socialist countries to promote the educational attainment of children from working-class families may be regarded as the "most fully developed form of meritocracy, of an education-based kind" (Bukodi and Goldthorpe 2010:656). 
In this study, we exploited the division and later reunification of Germany into the Federal Republic of Germany (FRG), a Western free-market economy, and the socialist German Democratic Republic (GDR) to investigate the impact of these different political systems and the associated institutional and socioeconomic context on the degree of IEO. Compared to other transition states, the German case is unique in allowing us to compare IEO in East Germany before and after reunification with West Germany, from which policies were adopted. Using survey data from multiple sources gives us the opportunity to study differences in IEO between the FRG and GDR and to investigate whether the adoption of the West German political, economic, and educational system after reunification led to a convergence of IEO in East and West Germany. This natural experiment will provide us with important insights into how very diverse macro-level factors shape IEO in contemporary societies. Data from the German Microcensus further allow us to consider variation in the development of IEO across East German Länder (federal states), which due to the Länder-specific adoption of West German educational features sheds further light on how differences in education systems affect IEO. To improve upon knowledge into the processes underlying the trends in overall IEO levels, we studied changes in educational attainment rates of individuals with parents from lower and higher social origin separately.

Although there is a comprehensive body of literature on trends in IEO in West Germany (Blossfeld 1993; Heineck and Riphahn 2009; Henz and Maas 1995; Jonsson, Mills, and Müller 1996; Klein et al. 2010; Meulemann, 1992; Müller and Pollak 2016; Schimpl-Neimanns 2000), few studies compared IEO between East and West Germany prior to reunification. These find that IEO levels were less strong in the GDR than in the FRG (Hadjar and Berger 2010; Sieben, Huinink, and De Graaf 2001). Regarding IEO after reunification, Kesler (2003) identified stability and, if anything, a decline in East Germany, whereas Riphahn and Trübswetter (2011) found that IEO rose in East Germany and was even higher than in West Germany at the beginning of the 2000s. von Below, Powell, and Roberts (2013) further showed that East German Länder experienced higher levels of IEO when they adopted a highly stratified system along with a more "traditional" curriculum (e.g., emphasis on classic and humanist subjects and centralized final exams) from West German Länder.

In our study, we advance the literature by describing the development of IEO in both East and West Germany across birth cohorts from 1930 until several years after reunification. To this end, we used all available microdata for this period that we deemed suitable: the German Life History Study (GLHS), the German General Social Survey (GGSS), and the German Microcensus (GMC).

\section{A Comparative View of East and West Germany over Time}

\section{Education Policy in West Germany}

The West German education system typically sorts children at a very early stage

(aged around 10 or 12, depending on the federal state) into Hauptschule (lower sec- 
ondary track), Realschule (intermediate secondary track), and Gymnasium (upper secondary track). Customarily, the Gymnasium has been the only track that has given students eligibility to enter higher education via the Abitur-the qualification achieved through the final exams at the end of upper secondary education. Student mobility between these school tracks is rare (Schneider 2008).

Over time, there have been extensions of nonstandard pathways to the Abitur and the introduction of different types of Abitur at vocationally oriented schools, such as those that allow access to technical colleges or specific fields of study. These nonstandard pathways facilitated the achievement of eligibility for higher education in recent periods (e.g., Köller, Watermann, and Trautwein 2004; Schindler 2014).

The Länder have the legislative and administrative authority in educational affairs (Kulturhoheit der Länder). However, the Standing Conference of State Education Ministers (Kultusministerkonferenz) ensures a high degree of comparability of educational qualifications across German Länder. Nevertheless, in the 1970s, some Länder introduced Gesamtschulen, in which the three different tracks run parallel inside one institution. In a unique form (Integrierte Gesamtschule) students remain together but are taught in different subject-specific levels while achieving different final certificates. ${ }^{1}$

There are Länder differences in how they sort students into different school tracks. In some Länder, parents can decide their children's secondary school track, whereas in others, teacher evaluation and strict requirements, such as minimum grade levels, are decisive. Some Länder also combine Hauptschule and Realschule into one school type. The age when students make the transition to secondary school also varies between Länder. In many Länder, the transition is at age 10 or was changed from age 12 to age 10 in the 1950s; in others, the age is 12 (see Table A1 in the online supplement for an overview of institutional differences across West German Länder).

In West Germany, vocational schools and business firms coordinate training that equips students with highly occupation-specific skills rather than general knowledge through classroom and in-work education (Müller, Steinmann, and Ell 1998). Today, around one-third of Abitur holders participate in the vocational training system after gaining the Abitur (Heine, Spangenberg, and Lörz 2007).

Given these institutional arrangements (early tracking, low permeability between tracks, and an attractive dual system of apprenticeship), IEO in West Germany is unusually high by international standards (Breen et al. 2009; Pfeffer 2008). Whereas some studies found persistent social inequalities in educational attainment over time (Blossfeld 1993; Heineck and Riphahn 2009; Meulemann 1992), others showed that IEO has decreased across birth cohorts in West Germany (Henz and Maas 1995; Jonsson et al. 1996; Klein et al. 2010; Müller and Haun 1994; Müller and Pollak 2016; Schimpl-Neimanns 2000).

\section{Education Policy in East Germany}

Under the GDR, the education system was less stratified than in West Germany. The Socialist Unity Party of Germany (SED) implemented policies centrally throughout the GDR's existence, and the education ministry of the central state administered 
a homogenous education system. From 1950 onward, all students attended a comprehensive school (the Polytechnische Oberschule [POS]) for 10 years, where low-achieving students experienced significant support and high-performing students received considerably less (von Below 2017).

After compulsory school at Grade 8, the education system offered the opportunity to change from POS to the Erweiterte Oberschule (EOS). The EOS led to a certificate of Abitur, allowing entry into university, and almost every student who obtained the Abitur successfully enrolled. After 1983, the transition to EOS happened after Grade 10 (Winkler 2017). Access to the EOS was strictly regulated, restricted, and based on prior achievement and (especially between 1945 and 1965) on the social class and political engagement of parents (Baske 1990; von Below 2017). Children of industrial and agricultural workers were prioritized, which was in line with socialist doctrine.

After completion of the POS, students were also able to opt for an apprenticeship or training in a vocational college, the latter being mostly for social, pedagogical, or artistic jobs. Unlike in West Germany, vocational schools were established within state production units, indicating strict state-regulated access to, and allocation within, the vocational system in the GDR.

From the mid-1960s, the socialist state sharply reduced the "positive discrimination" of worker children. Those who had benefited from this process, the socialist intelligentsia who had been the first school-leaver cohorts to spend their entire education under the GDR, wanted their children to be equally successful (von Below 2017; Brock 2009). ${ }^{2}$ High-performing students with no personal or parental affiliation with the SED and those who exhibited limited socialist attitudes and behaviors had minimal chances of accessing the EOS (von Below 2017; Fischer 1992). Simultaneously, the link between parents' education and SED membership and governmental or administrative positions was marked (Fuller 1999). In the early 1970s, the GDR also halted university expansion and reduced the number of studentships.

\section{IEO before Reunification}

Two principal arguments predicting larger IEO in the FRG than in the GDR emerge from our discussion of the institutional and political contexts before reunification. According to the "market-versus-meritocracy" argument (Bukodi and Goldthorpe 2010), intergenerational social reproduction will always be a considerable factor in free-market economies, as privileged students profit from their upbringing with higher abilities and resources. Bukodi and Goldthorpe (2010) further argue that command economies, such as the GDR, come closer to an educationally meritocratic ideal because they explicitly intervene against intergenerational reproduction by imposing meritocracy and explicit policies to reduce inequalities. Therefore, we expect IEO to be more significant in a "choice-based system," such as the FRG, than in an "imposed system" based on academic achievement and limited choice of educational pathways, such as the GDR (Kesler 2003). As the GDR abandoned some policies tackling intergenerational reproduction after 1965 (e.g., Brock 2009), we can assume IEO increased from this point onward. 
Secondly, the FRG's highly selective early tracking system, in contrast to the GDR's comprehensive school system, would suggest a considerably larger IEO. Because the transition to upper secondary school occurred later in the GDR than in the FRG, (lower-class) students in the east had more time to develop their full potential before segregation into different educational tracks (Erikson and Jonsson 1996; Müller and Karle 1993). Additionally, social stratification in school performance is likely to be more potent in the FRG, as earlier segregation into a lower school track meant students from lower socioeconomic backgrounds had less time to benefit from the presence of more able and motivated students before segregation (Lavrijsen and Nicaise 2016). Different school tracks may also differ in curricula quality, sorting teachers by qualifications, educational expectations or financial resources. Overall, early tracking systems were shown to reinforce the gap in academic achievement between social and comprehensive systems (e.g., Hanushek and Wößmann 2006; Schütz, Ursprung, and Wößmann 2008).

When students are allocated to different tracks at an early age, it is also more difficult for them to assess their ability or "likelihood of success" than when they are older, as available information to them at these early transition points is limited (Jackson and Jonsson 2013). Students are less dependent on their parentseconomically and socially-during later transitions, and parents' characteristics should therefore matter less in students' educational decision-making (Müller and Karle 1993). In an experimental design, late tracking decreased IEO by reducing uncertainty in educational-decision making for lower-class students (Berger and Combet 2017). Overall, the introduction of comprehensive schooling in other countries led to a reduction in social inequalities in educational attainment (Erikson 1996; McPherson and Willms 1987).

Our research questions are as follows: Was IEO weaker in the GDR than in the FRG (Research Question 1 [RQ1])? Were there any changes in IEO during the existence of the GDR due to changes in policy (reduced positive discrimination from the mid-1960s and later tracking decision from the mid-1980s [Research Question 2 (RQ2)])?

\section{IEO after Reunification}

After reunification, the two features designed to reduce IEO in the GDR-positive discrimination and comprehensive schooling-were replaced with a tracked education system adopted from West Germany along with a free-market economy. The abolition of positive discrimination and the expansion of upper secondary education should have led to an increase in IEO postreunification via families' status maintenance motives and class-specific cost-benefit calculations. As students of higher social origin were freer to transform higher abilities and parental resources into an educational advantage, we expect considerably higher rates of Abitur among more advantaged children postreunification. In contrast, "protected routes to upward mobility for children of lower-class origin are taken away" (Jackson and Evans 2017:59), and this should have led to a limited uptake of Abitur among lower-class children postreunification. 
Newly established Länder in East Germany were assigned partner Länder in the west, from which the majority adopted their education systems (von Below et al. 2013; Goedicke 2006). For an overview of institutional changes in each East German federal state after reunification and until the year 2004 (the year until which birth cohorts are affected by institutional changes in our analysis), see Table A2 in the online supplement. As all Länder changed from a comprehensive schooling system to a tracked system and the decision on school tracks was now made earlier in a child's life across all Länder, it is reasonable to expect IEO to have increased postreunification and converged with the West German level.

The introduction of West Germany's model created more stratification in the education systems of East German Länder than there had previously been. MecklenburgVorpommern, Sachsen, Sachsen-Anhalt, and Thüringen lowered the age of students when they enter different tracks from 16 to 10 years of age. East Berlin and Brandenburg lowered the age of tracking to 12 years of age (Freitag and Schlicht 2009; see Table A2 in the online supplement).

Furthermore, the decision-making process used for transition to secondary schooling varied with reunification. Although schools and the central state had strictly regulated this process under the GDR, some new Länder adopted a system in which parents made the final decision (East Berlin, Brandenburg, MecklenburgVorpommern, and Sachsen-Anhalt), and others adopted a model in which teachers decided (Sachsen and Thüringen). Dollmann (2016) found that the effect of social origin on school-track choices is less significant in Länder where teacher recommendations are binding than in those where they are nonbinding and parents make the final decision. This illustrates that higher-class students benefit from education systems that allow for parental choices.

Thirdly, Länder differed in the implementation of the West German tripartite school system after reunification. Only East Berlin, Brandenburg, and MecklenburgVorpommern introduced all three different school tracks. Sachsen, Sachsen-Anhalt, and Thüringen distinguished only between Gymnasium and a combination of the lower tracks. Hence, Länder differed in the degree of tracking during our observation period.

According to our theoretical assumptions, IEO should have increased to a higher degree in East German Länder, in which the sorting mechanism prevailed most (i.e., students were sorted into three different school tracks, parents decided on the school track, and tracking happened at age 10 rather than 12; see Table A2 in the online supplement). Table 1 shows how changes in all three factors may have influenced IEO in our observation period. The fields denoted with "++" should lead to more pronounced social inequality, and those denoted with " + " should also lead to increasing inequality but to a lesser extent. From this, we can conclude that we should observe the strongest increase in IEO in Mecklenburg-Vorpommern due to a high level of tracking, educational decisions made at 10 years of age, and parents deciding on their children's school track. Brandenburg, Sachsen-Anhalt, and East Berlin are in an intermediate position. According to this table, we can expect the smallest increase in IEO in Sachsen and Thüringen.

Following these considerations, we address the following research questions: Has IEO in East Germany converged with the West German level after reunification 
Table 1: Institutional changes (until 2004) and predicted development of social inequality in educational opportunity.

\begin{tabular}{lccc}
\hline Länder & Tracking degree & Timing of tracking & Tracking decision procedure \\
\hline East Berlin & ++ & + & ++ \\
Brandenburg & ++ & + & ++ \\
Mecklenburg-Vorpommern & ++ & ++ & ++ \\
Sachsen & + & ++ & + \\
Sachsen-Anhalt & + & ++ & ++ \\
Thüringen & + & ++ & + \\
\hline
\end{tabular}

(RQ2a)? Is there evidence that IEO increased to a larger extent in East German Länder, in which tracking configurations should favor children from higher socioeconomic backgrounds (RQ2b; see Table 1)?

Transferring from a demand economy to a free-market economy may have also had consequences for IEO. After reunification, East Germany quickly installed West German economic institutions (Diewald, Solga, and Goedicke 2002; Gebel 2011). From the end of 1989 to the middle of 1992, East Germany's economic system experienced extensive restructuring involving the closing of the majority of large state-led companies, downsizing of firms, and the emergence of numerous business start-ups. This restructuring led to severe labor-market turbulence, resulting in direct firm shifts, upward and downward mobility, and rising unemployment rates (Diewald et al. 2002). From mid-1992, East Germany experienced a time of economic stagnation (Mickler et al. 1996).

The drastic changes in the economic system also affected the vocational training system (Gebel 2011). The economic downturn meant that enterprises were unable to afford apprentice positions, compelling their increase in state-subsidized, external training facilities (Grünert, Lutz, and Wiekert 2006). The GDR's birth policies in the 1970s led to a rise in the number of school leavers from the mid-1990s onward, so the few available apprenticeship positions were quickly filled (Troltsch, Walden, and Zopf 2009). Young people with vocational qualifications experienced increasing difficulty finding jobs (Gebel 2011).

According to the "discouraged worker effect," weak labor-market conditions, such as unemployment and low wages, influence students' decisions to remain in school beyond compulsory education (e.g., Micklewright, Pearson, and Smith 1990; Raffe and Willms 1989). Poor economic conditions suggest to students that benefits from entering the labor market, and in turn costs of schooling, are low. Consequently, staying in school to attain the Abitur, instead of attending vocational education or dropping out, may have been an increasingly popular option in East Germany immediately after reunification.

Despite a rise in overall wages, the transformation from a command economy to a free-market economy in East Germany led to rising income inequality and increasing disparities between families' resources (Frick et al. 1995; Headey, Andorka, and Krause 1995). As some families' resources became increasingly constrained (for example, through parental unemployment), students of those less-advantaged 
backgrounds may increasingly have chosen the less costly and shorter, vocationally oriented tracks or entered the labor market directly in order to be less dependent on the financial support of their families or to provide further financial help to their families.

Students of higher social origin may have been more inclined to continue with education because their parents were more aware of the economic consequences of reunification, such as decreasing employment opportunities, declining social mobility, and problems in the vocational training system. In several experimental designs, information deficits of students from lower social backgrounds were important mechanisms in choosing lower educational tracks (e.g., Barone et al. 2017; Ehlert et al. 2017). Higher-class parents may also have had more knowledge about the strong link between education and occupational attainment in West Germany.

Employers increase hiring standards and the sorting of job applicants by their educational qualifications during economic downturns (Wolbers, De Graaf, and Ultee 2001). This process could have influenced families' educational decisionmaking: Students from higher social backgrounds felt more pressure to invest in education under adverse macroeconomic conditions to preserve their families' social status. Those families who had been relatively well off at the time of reunification were those who felt the most dissatisfied with their incomes in the years after reunification (Headey et al. 1995). This also seems to indicate that higher-status families were particularly worried about maintaining their status.

Drawing on these considerations, we ask the following research question: Did IEO in East Germany sharply increase after reunification due to an economic shock (RQ2c)?

\section{Method}

\section{Data}

To describe the long-term development of IEO in East and West Germany, we use a variety of German microdata. The German Life History Study (GLHS) is ideal for identifying differences in IEO between the FRG and the GDR for the birth cohorts who finished school before reunification (Mayer 2008). The German General Social Survey (GGSS) allows us to compare changes in IEO in both parts of Germany before and after reunification. The German Microcensus (GMC) is valuable for studying IEO at the time of reunification and after until the most recent school-leaver cohorts and, because of the relatively large sample size, for assessing development at the level of the (eastern) Länder. The GLHS only selected German citizens in its sample. Our sample therefore excludes non-German citizens to achieve comparability of samples across the observation period.

Figure 1 gives an overview of the birth cohorts included in our different data sets. The vertical, dashed, gray line in this figure indicates the crucial timing of reunification for birth cohorts' educational decision-making. All East German birth cohorts on the left of this line (until 1973) were selected into upper secondary education before reunification. All Eastern German birth cohorts on the right of this line (starting in 1974) were segregated after reunification. 


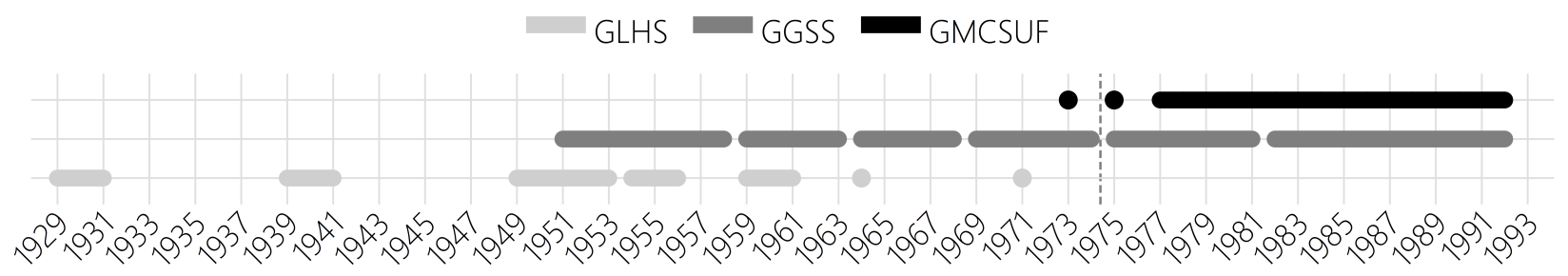

Birth cohort

Figure 1: Classification of birth cohorts across different surveys.

The GLHS provides retrospective information on several nationally representative birth cohorts, with the oldest cohort being born in 1919 and the youngest cohort being born in 1971. These surveys were carried out in face-to-face interviews and computer-assisted telephone interviews between 1981 and 2005. The GLHS includes survey information on life histories for more than 12,000 respondents. For West German residents, we use retrospective information on the following seven birth cohorts: 1929 to 1931, 1939 to 1941, 1949 to 1951, 1954 to 1956, 1959 to 1961, 1964, and 1971 (Mayer 1995a, 1995b; Mayer and Kleinhenz 2004). For East German residents, data on five birth cohorts are available: 1929 to 1931, 1939 to 1941, 1951 to 1953, 1959 to 1961, and 1971 (Mayer 1995c, 2004). Due to the retrospective nature of the study, we used information on educational attainment from all respondents in the different birth cohorts at the time of the survey. The total number of cases is 6,536 for West Germany and 2,819 for East Germany (see Table A3 in the online supplement for the number of cases in each cohort and each part of Germany).

The GGSS is a biennial, cross-sectional, face-to-face survey of the adult population of Germany from 1980 onward. After reunification, an additional survey was conducted in 1991. In our analysis, we used waves 1991 to 2016, including information on East German residents (GESIS Leibniz Institute for the Social Sciences 2016, 2017). We restricted the respondents to those aged 22 to 40 years at the time of the survey to include most of the individuals who completed upper secondary schooling. We identify schooling in East and West Germany by residence at the time, supplemented by information on place of residence at birth, or in adolescence for respondents born before 1990. The total number of cases is 7,454 for West Germany and 4,208 for East Germany (see Table A4 in the online supplement for the number of cases in each cohort and each part of Germany).

The GMC is a representative survey of the German population, covering 1 percent of all German households. It was conducted annually in West Germany since 1957 and in East Germany since 1991. We used the following de facto anonymized scientific use files (SUFs), which are 70 percent subsamples of the original sample: 1991, 1993, 1995, and annual information for the years 1996 to 2010. Because the GMC does not include any direct information on children's social backgrounds, we used the contextual household information on their parents' education to generate this information. As recommended for GMC research on links between social origin and educational attainment (Klein et al. 2010; Schimpl-Neimanns 2000), our analy- 
sis focuses on 18-year-olds because the overwhelming majority in this age group still lives with their parents. ${ }^{3}$ Based on these data, we cover cohorts born between 1973 and 1992, thus including one cohort (1973) that was segregated into secondary school tracks before reunification and a long observation period of cohorts that entered secondary school tracks postreunification. The total number of cases is 61,864 for West Germany and 16,757 for East Germany (see Table A5 in the online supplement for the number of cases in each cohort and each part of Germany).

\section{Measures}

Our measurement of educational attainment is a binary variable indicating whether individuals attained or did not attain the Abitur. The Abitur is not only a prerequisite for gaining access to higher education and, in turn, for better labor-market returns but is increasingly demanded to gain access to the most prestigious apprenticeships in the FRG and both parts of Germany after reunification. In the GDR, gaining the Abitur was practically equivalent to attending university. Placement of university graduates in the labor market was strongly regulated, and the number of accepted university students was in line with the regime's five-year economic plan.

The dependent variable in the GMC data deviates from the other data sources in two respects. Firstly, we look at the participation rates of 18-year-olds in upper secondary education (Gymnasium, grades 11-13). Secondly, participation rates are restricted to the general Gymnasium and do not cover the technically oriented Gymnasium and delayed Abitur attainment in later life. Although measurement of Abitur attainment is not strictly comparable across data, it should be internally consistent across birth cohorts within data. For Germany, we also know that there is low mobility between tracks after the initial sorting into secondary education and that the Abitur via a general Gymnasium is still the main route of gaining eligibility for higher education (Hillmert and Jacob 2010).

We measure social origin with the father's education. In case we do not have information on the father's education, we use the mother's education. We differentiate between pupils who have a father (or mother) with Abitur and pupils who have a father (or mother) with a qualification below the Abitur.

\section{Analysis}

We use the difference in Abitur attainment rates by parental education as our measure of IEO. To calculate this difference, we rely on a fully interacted logistic regression model of Abitur attainment on parental education, birth cohort, and region. For ease of interpretation, we also provide estimates for the difference in IEO by region. In the final analysis, using GMC data and aggregated birth cohorts, we provide estimates for East German Länder with similar tracking arrangements separately (see Table A6 in the online supplement for the number of cases in each cohort). 

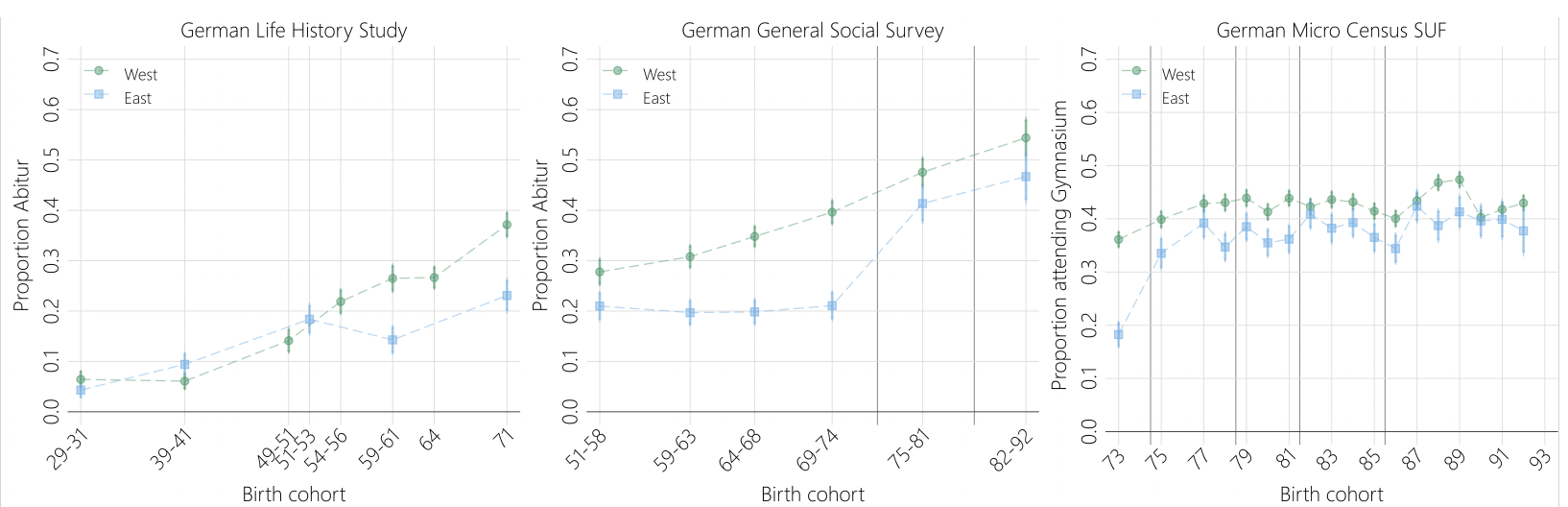

Figure 2: Change in percentage of Abitur attainment (GMC: proportion attending Gymnasium) across birth cohorts in East and West Germany. The first vertical line indicates the timing of reunification. Subsequent vertical lines differentiate birth cohorts according to the timing of educational transitions after reunification.

\section{Results}

\section{General Abitur Rates}

Figure 2 illustrates trends in Abitur rates across birth cohorts in East and West Germany in all three data sets along with the 90 percent and 95 percent confidence intervals. Based on GLHS data, the graph shows that in the early stages of the GDR (cohorts 1929-1931 and 1939-1941), the percentage of individuals attaining the Abitur did not significantly differ from those in the FRG. Both the FRG and the GDR Abitur rates increased from birth cohort 1939 to 1941 onward at a similar rate until the cohorts born around 1950. Whereas Abitur rates continued to grow among 1950s birth cohorts in the FRG, we saw a decrease in the percentage of individuals attaining the Abitur in the GDR. Among 1960s cohorts, a significant divergence in Abitur rates between the FRG and the GDR is evident in the GLHS data and the GGSS data. For cohorts that were channeled into the Abitur track before reunification, this gap tends to be more pronounced in GGSS data (almost 20 percentage points) than in GLHS data.

The Abitur rate (GGSS) and the proportion of pupils attending Gymnasium (GMC) rose more strongly in East Germany than in West Germany among cohorts that transitioned into different school tracks after reunification. Abitur rates in both parts of Germany ran parallel for cohorts born at the end of the 1970s onward; however, the percentage of students attaining the Abitur (GGSS) or attending Gymnasium (GMC) in East Germany has consistently remained slightly below the West German level. Overall, we find clear evidence that the percentage of individuals with Abitur converged postreunification.

\section{Social Inequalities in Abitur Rates}

Figures 3 to 5 show IEO across birth cohorts for GLHS, GGSS, and GMC data. For both West and East Germany, the left-hand graphs illustrate trends in Abitur 

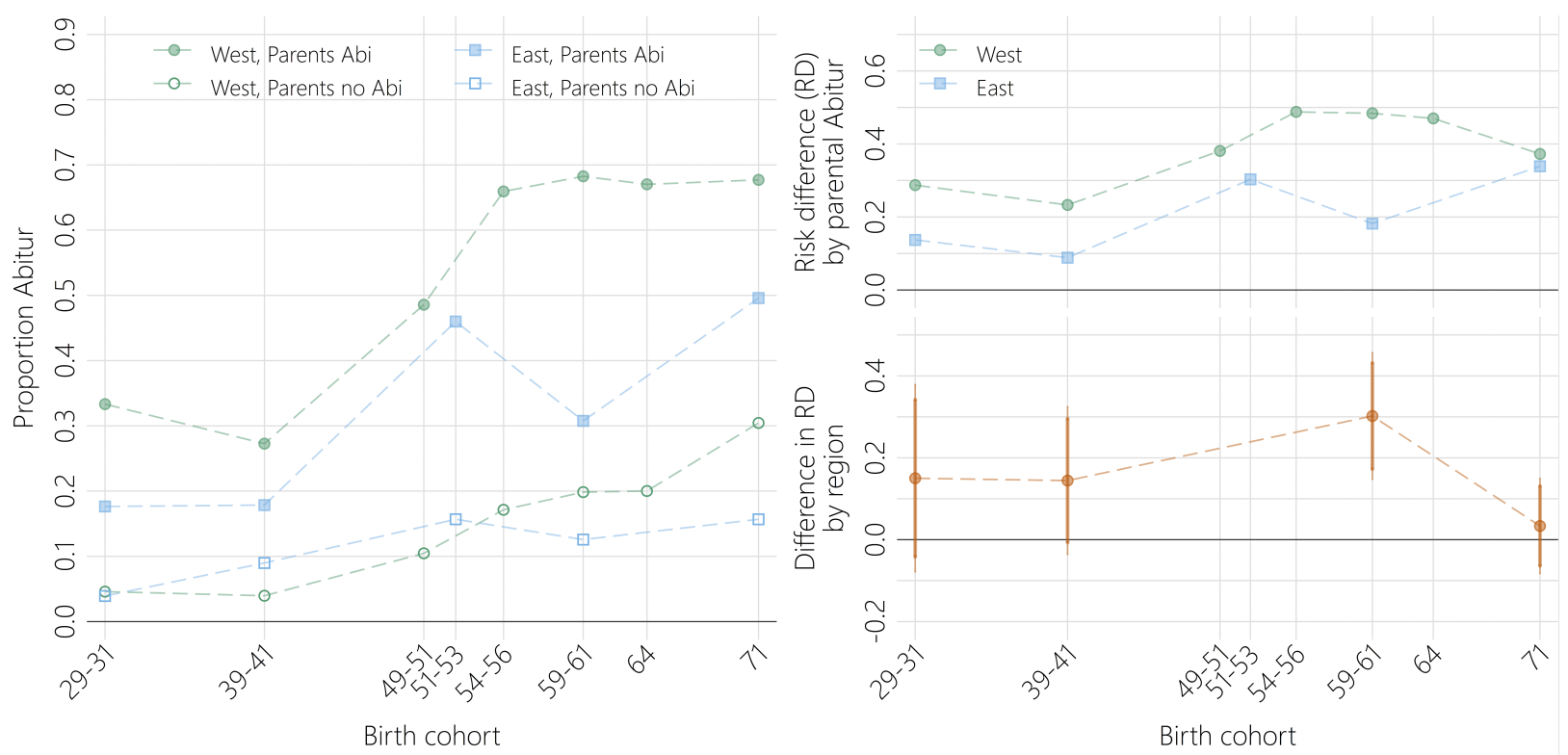

Figure 3: Change in IEO across birth cohorts in East and West Germany before reunification. Risk differences pertain to parental education. Difference in risk difference pertains to East and West Germany.

rates across birth cohorts for children who have at least one parent with an Abitur and those who do not. The upper-right graphs illustrate risk differences between children whose parents are Abitur holders and those who are not. The lower-right graph shows the difference in risk differences between East and West Germany along with 90 percent and 95 percent confidence intervals.

The GLHS data in Figure 3 cover birth cohorts in the FRG and the GDR that transitioned into upper secondary school tracks before reunification. Among the oldest cohorts (1929-1931 and 1939-1941), the percentage who have non-Abiturholding parents but go on to hold Abitur themselves is small and similar across both the FRG and the GDR. For cohorts born in the 1940s, this number increased in both countries. The percentage of students whose parents are not Abitur holders and go on to attain Abitur continued to rise in the FRG but stagnated in the GDR for cohorts born from the 1950s onward; they therefore had a higher probability of attaining the Abitur in the FRG.

Students with Abitur-holding parents were far more likely to attain Abitur in the FRG than in the GDR among the oldest birth cohorts (1929-1931 and 1939-1941). In the FRG, Abitur attainment rates rose steeply for this group among the 1940s and 1950s birth cohorts. This expansion hit the ceiling with 1960s birth cohorts, and it was less-advantaged students who began experiencing an uptick in Abitur attainment. In the GDR, Abitur rates among individuals who had at least one parent with Abitur mirrored the general GDR rate and growth. If opportunities were more pronounced or more restricted, it was primarily individuals from more-advantaged backgrounds who used improved opportunities to attain the Abitur or were held back by the system. Consequently, the FRG-GDR gap in Abitur rates among advantaged children narrowed for cohorts born in the 1940s, widened sharply for 

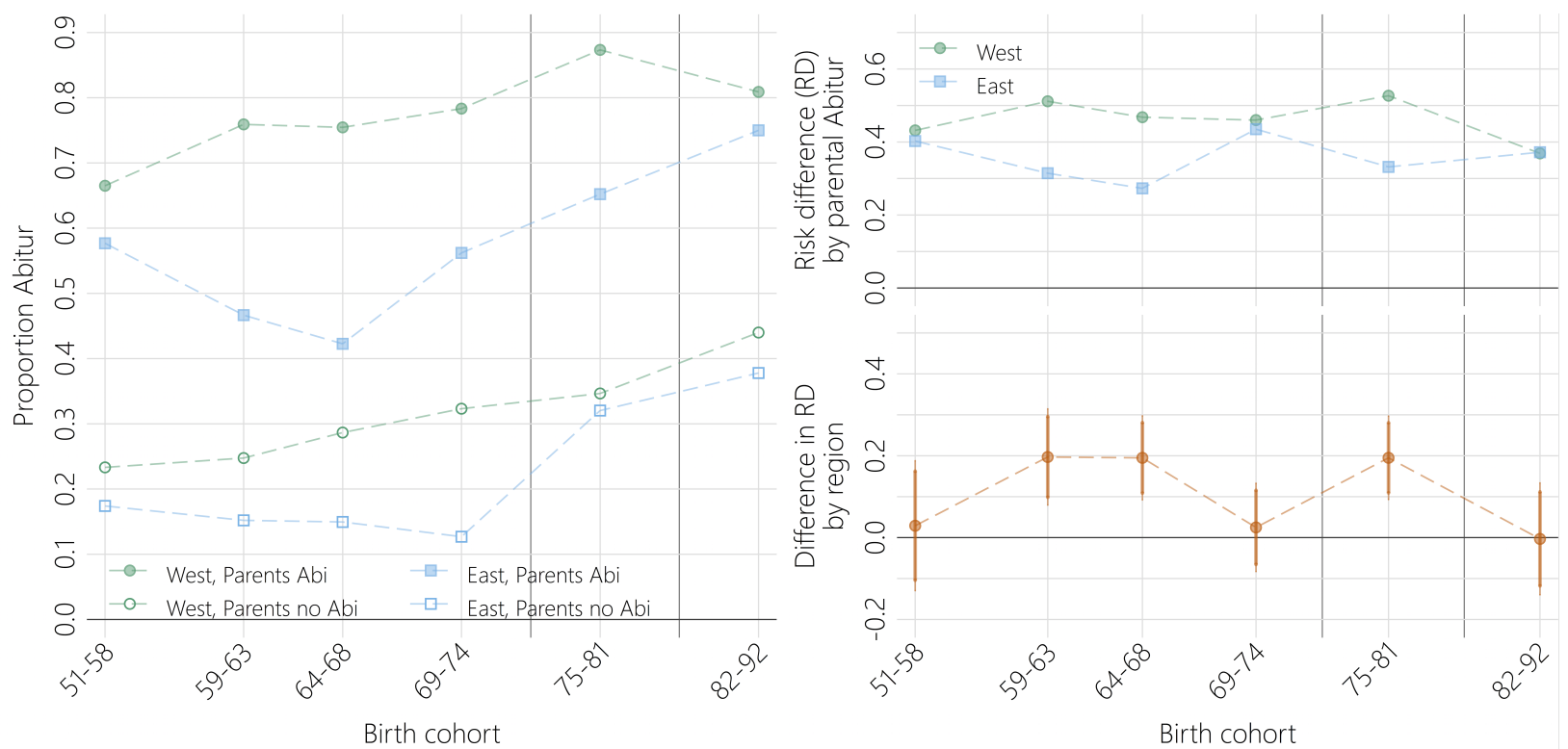

Figure 4: Change in IEO across birth cohorts in East and West Germany before and after reunification. Risk differences pertain to parental education. Difference in risk difference pertains to East and West Germany. The first vertical line indicates the timing of reunification. Subsequent vertical lines differentiate birth cohorts according to the timing of educational transitions after reunification.

1950s birth cohorts, and narrowed again for cohorts entering the secondary school track before reunification.

Due to these group differences, IEO (upper-right graph) was far higher in the FRG than in the GDR for the oldest birth cohorts. Because Abitur rates among those with Abitur-holding parents expanded from the 1940s birth cohorts, IEO increased in both countries. For cohorts born in the 1950s, IEO decreased in the GDR and remained stable in the FRG, leading to the most significant gap in IEO between the two during our observation period. Again, we can attribute this to decreasing levels of Abitur attainment in the GDR among those whose parents are also Abitur holders. For cohorts born in the 1960s (i.e., individuals segregated into the upper secondary school track in the 1970s), levels of inequality became similar in the FRG and the GDR due to increased IEO in the GDR and decreased IEO in the FRG.

We can also identify social inequalities in Abitur attainment rates in the GGSS data for cohorts born in the 1950s and later (Figure 4). The GGSS data reveal a similar pattern as the GLHS data for cohorts born between 1950 and those segregated into the secondary school track immediately before reunification. Firstly, Abitur attainment rates for individuals with Abitur-holding parents in the GDR decreased in the 1950s and increased again in the 1960s cohort. Secondly, Abitur attainment rates among students whose parents are not Abitur holders were lower in the GDR than in the FRG and did not change among cohorts entering the secondary school track immediately before reunification. Again, we can observe that changes in the GDR's IEO are principally due to shifting rates among students with parents who are Abitur holders. Thirdly, Abitur attainment rates for students who do not have 

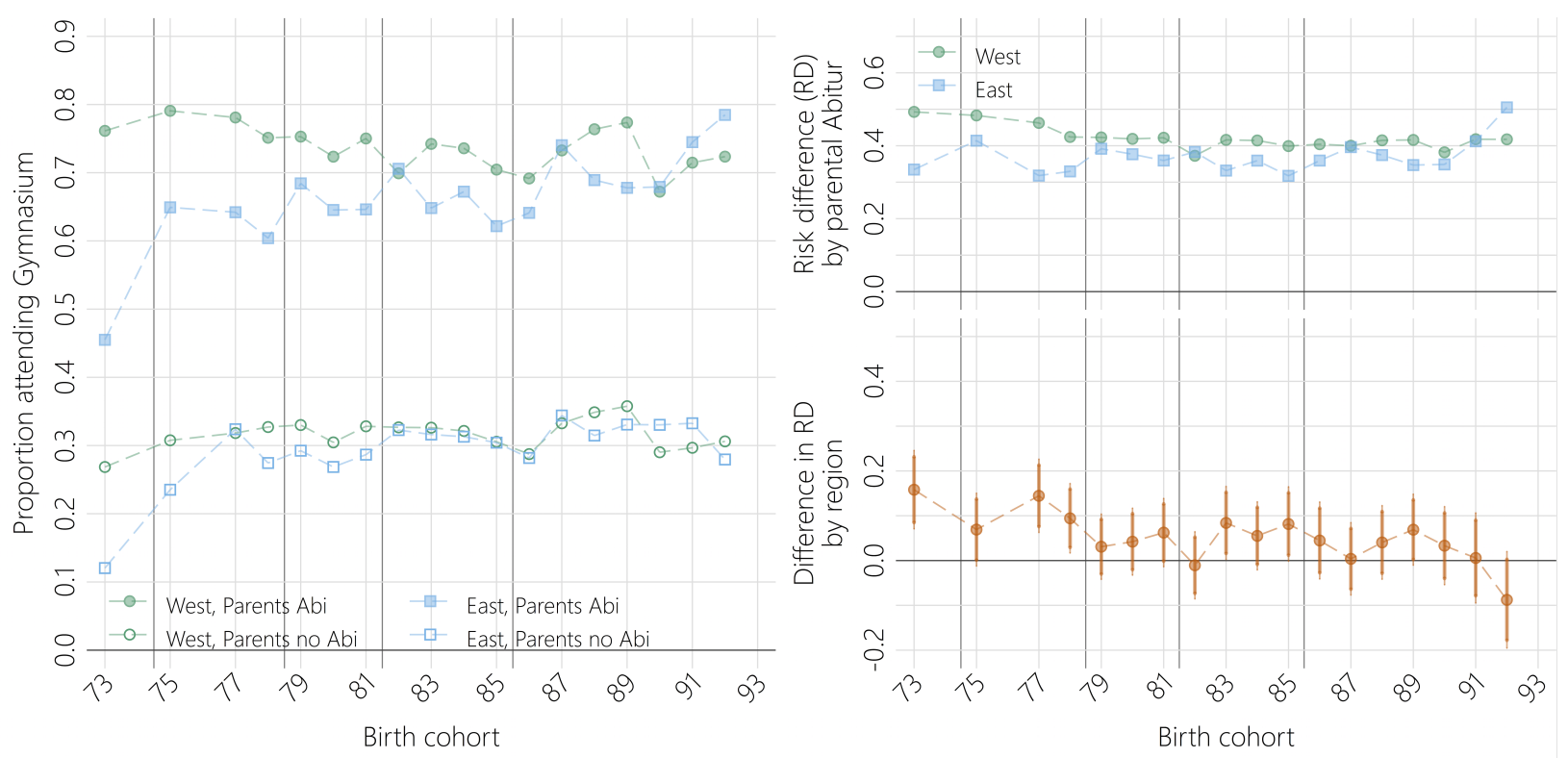

Figure 5: Change in IEO across birth cohorts in East and West Germany after reunification. Risk differences pertain to parental education. Difference in risk difference pertains to East and West Germany. The first vertical line indicates the timing of reunification. Subsequent vertical lines differentiate birth cohorts according to the timing of educational transitions after reunification.

Abitur-holding parents increased in the FRG for the 1960s and 1970s cohorts. As with the GLHS data, the gap in IEO between the FRG and the GDR was the largest for cohorts born in the 1950s until mid-1960s and smallest for cohorts entering the secondary school track just before reunification.

Hence, in both GLHS and GGSS data, IEO in the GDR increased in the prereunification cohort and became increasingly similar to the FRG level when compared to previous birth cohorts. ${ }^{4}$ However, the level of IEO in the GDR consistently remained below the level of the FRG.

Figure 4 also illustrates changes in Abitur rates for both educational groups after reunification. In the GGSS data, we differentiated birth cohorts 1975 to 1981 and birth cohorts 1982 to 1992 . The former was aged 10 to 16 in the school year 1991 to 1992 and transitioned into the secondary school track immediately after reunification reforms took place. The latter faced the prospect of upper secondary schooling when these reforms were more established. All East German students of the birth cohorts increased their attainment rates postreunification, but the increase was more pronounced for those whose parents were not Abitur holders. Consequently, and contrary to expectations, IEO declined across East Germany postreunification in the GGSS data (see upper-right graph). For the later birth cohort of 1982 to 1992, who entered the secondary track when reforms were more established, both groups continued to increase their attainment rates; however, for this cohort, the increase was slightly stronger among individuals whose parents were Abitur holders. To summarize, according to the GGSS data, the level of IEO in East Germany postreunification was lower than for those cohorts who completed 
school before reunification. For West German birth cohorts born between 1975 and 1981, Abitur attainment increased, but this was more modest among children whose parents were not Abitur holders. For West German birth cohorts 1982 to 1992, however, we see opposing developments; whereas individuals whose parents are not Abitur holders continued to be more likely to gain the Abitur, individuals with highly educated parents showed a decline in attainment rates. The upper-right graph shows that the levels of IEO between East and West Germany converged again, but this time at a lower level.

Based on GMC data, Figure 5 shows the development of social inequalities in attending Gymnasium shortly before (birth cohort 1973) and after reunification. The 1975 to 1978 birth cohorts transitioned into the secondary school track in 1991 and 1992 during the reformation of the education system in East Germany, at which point the age of tracking shifted from 16 years of age to 10 or 12 years of age. Birth cohorts of either 1979 (tracking at age 12) or 1981 (tracking at age 10) were immediately confronted with the process of either decision on or selection into secondary school tracks upon the introduction of these reforms. Birth cohorts 1982 to 1985 had started elementary school under the GDR and were segregated into secondary schooling after reunification. Birth cohorts 1986 to 1992 were the first to begin elementary school after reunification.

In the GMC data, the difference in IEO between the FRG and the GDR prereunification is more pronounced than in the GLHS and GGSS data. For the prereunification cohort, the difference in risk differences between both countries is around 15 percentage points. Similar to in the GGSS data, there was an increase among all students who entered the Abitur track postreunification independent of parental educational achievement. For the 1975 birth cohort (age 16 at the time of segregation into secondary school tracks), we see a stronger increase in Gymnasium attendance among students with Abitur-holding parents than among those without parents with Abitur. It appears that 16-year-olds who do not have Abitur-holding parents were less inclined to take advantage of the new opportunities that reunification provided as their peers with more highly educated parents were. However, this is not the case for the 1977 birth cohort, when Gymnasium attendance rose more sharply for individuals without Abitur-holding parents. For the 1978 birth cohort, Gymnasium attendance decreased for both groups. In West Germany, IEO declined during this period due to increasing Gymnasium attendance among individuals without Abitur-holding parents and decreasing Gymnasium attendance among individuals with Abitur-holding parents. Although the Gymnasium attendance of individuals in East Germany without Abitur-holding parents caught up with the Gymnasium attendance of those in the west with the same background, there is still a notable gap in Gymnasium attendance for individuals with Abitur-holding parents between East and West Germany. Accordingly, IEO is still smaller in the east compared to the west for these cohorts.

For the East German birth cohorts of 1979 to 1981 (students were segregated during the 1991-1992 school year at 10 or 12 years of age), there was a more significant increase in the rate of attending Gymnasium among individuals whose parents have the Abitur than among those whose parents are not Abitur holders. As a result, we see an increase in IEO. Because IEO in West Germany was quite 
stable during this period, the level of IEO became more similar in East and West Germany for these cohorts.

Among students of the 1982 to 1985 birth cohorts whose parents are Abitur holders, the Gymnasium attendance rate was decreasing (compared to those of earlier years) to a stronger extent than for individuals whose parents do not have Abitur. Hence, we identified a decline in IEO in East Germany compared to in previous cohorts. However, the level of IEO in East Germany was still slightly higher than it was prereunification in most of the cohorts.

For the 1986 to 1992 East German birth cohorts, who spent their entire educational career in unified Germany, the level of IEO increased again, particularly for the last cohorts in our observation period. The level of IEO is even higher in East Germany than in West Germany for the 1992 birth cohort, as there was a more significant rise in Gymnasium participation among students with Abitur-holding parents than among students whose parents are not. For these cohorts, the rate of Gymnasium attendance for students with Abitur-holding parents became comparable across Germany. Overall, it is striking how similar Gymnasium attendance rates for individuals with the same parental background have become in both parts of the country postreunification.

In Figure 6, we compared the development of IEO in different East German Länder with the overall average of West German Länder after reunification. Due to variations in the adoption of West German education system characteristics, we expected IEO to increase the most in Mecklenburg-Vorpommern, less so in Brandenburg and Sachsen-Anhalt, and to the lowest extent in Sachsen and Thüringen.

Mecklenburg-Vorpommern appears to be an outlier in having had an exceptionally high level of IEO prereunification (risk difference of more than 65 percentage points) even compared to the West German average. However, we have to interpret this result with caution due to the small sample size (see Table A5 in the online supplement). Postreunification, the level of IEO in Mecklenburg-Vorpommern declined and converged with the West German level. As expected, IEO had been much lower for all other Länder in the GDR, especially for Brandenburg and Sachsen-Anhalt. We found an immediate increase in the level of IEO for all birth cohorts affected by reunification reform changes in Brandenburg and Sachsen-Anhalt. The level of IEO also increased postreunification in Sachsen and Thüringen and merged with the West German level. However, this increase was most pronounced for individuals who spent their entire educational careers in the unified and reformed German system (birth cohorts 1986-1992). Hence, reforms seem to have had a prolonged impact on social inequality in these Länder.

\section{Discussion and Conclusions}

In this article, we aimed to provide a detailed account of differences and changes in IEO in East and West Germany across reunification, thereby shedding light on the role of macro-level institutional and economic characteristics in shaping social inequalities in educational attainment.

Our empirical analyses showed that social inequalities in educational attainment were weaker in the GDR than in the FRG. We also found that IEO varied across 


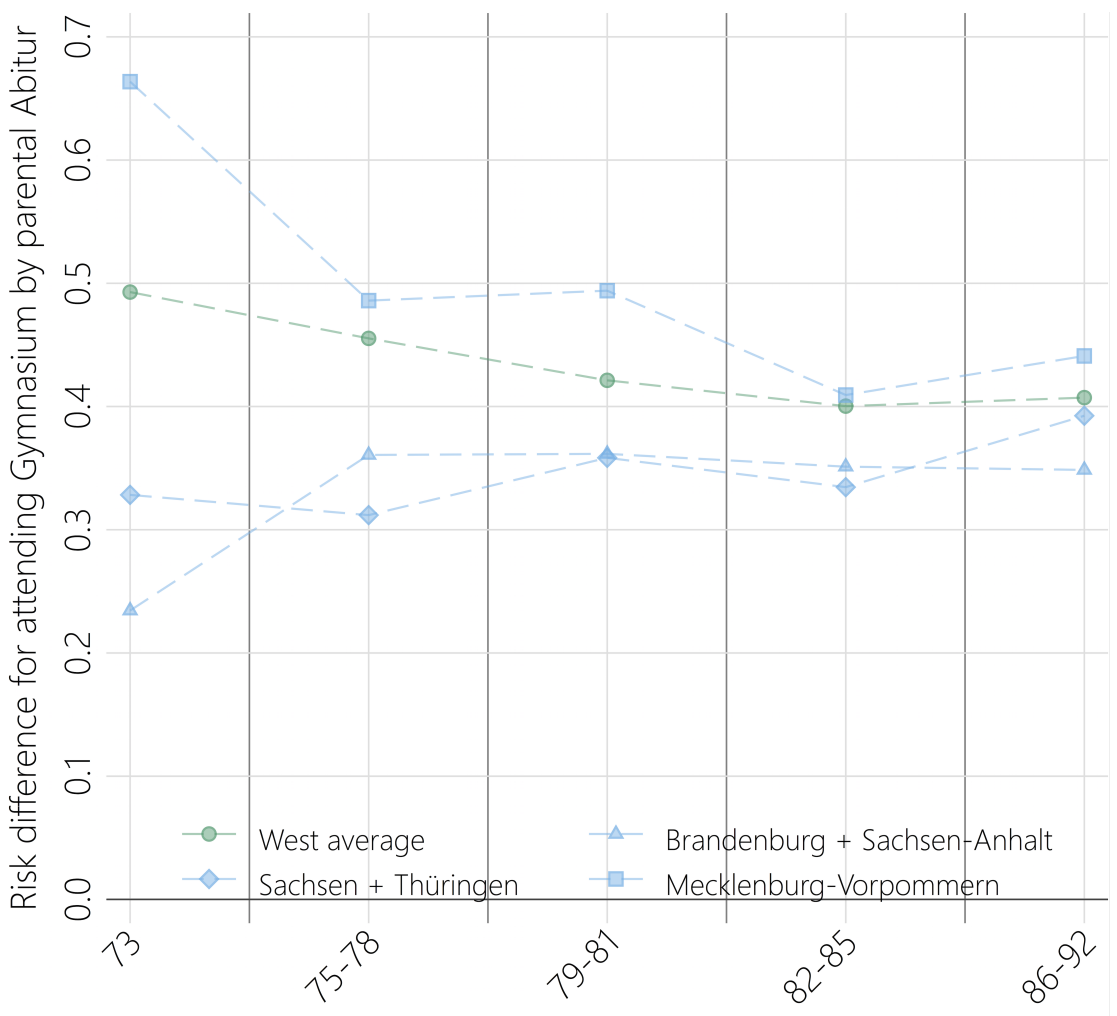

Birth cohort

Figure 6: Change in IEO across birth cohorts in East German Länder and the West German average. Risk differences pertain to parental education. The first vertical line indicates the timing of reunification. Subsequent vertical lines differentiate birth cohorts according to the timing of educational transitions after reunification.

periods in the GDR. Although IEO was smaller in the GDR than in the FRG in each cohort, it was substantially weaker for cohorts born between the 1950s and mid-1960s (that is, for individuals entering the secondary school track in the 1960s and 1970s). For cohorts born from the mid-1960s onward, IEO increased in the GDR and became similar to the level of IEO in the FRG in both the GLHS and GGSS data prereunification. The GMC data, however, still showed a substantial gap between IEO in the GDR and in the FRG immediately before reunification. Taking all three data sources into account, we conclude that IEO became stronger across the existence of the GDR but remained below that observed in the FRG before reunification.

By looking at the development of Abitur rates for children of parents with and without Abitur separately, we gained valuable insights into why IEO varied between the GDR and the FRG. Contrary to the GDR's policy aims, Abitur attainment rates were relatively similar among students who did not have Abitur-holding parents in both parts of Germany for cohorts born in the 1930s and 1940s. For subsequent cohorts, the probability of attaining the Abitur when parents did not have the Abitur was higher in the FRG than in the GDR. However, it was mainly 
the Abitur rates among individuals whose parents had attained the Abitur that strongly varied across the two political and educational settings before reunification. Individuals from advantaged educational backgrounds had a much higher probability of attaining the Abitur in the FRG than in the GDR. These results may indicate that GDR policies constrained higher-class students from exploiting their family resources and fulfilling their aspirations rather than supporting the notion that policies to promote working-class students were effective.

After reunification, IEO became increasingly similar in East and West Germany. We can attribute this convergence to both increasing inequalities in East Germany and declining disparities in West Germany, in particular for birth cohorts transitioning into the secondary school track immediately preceding reunification. The level of IEO in East Germany after reunification fluctuates across cohorts born in the 1980s but is remarkably similar to the West German level. For cohorts born at the beginning of the 1990s, we saw a sharp increase in the degree of IEO in East Germany that was even more pronounced than West German levels. This increase in the level of IEO in East Germany is due to a more significant rise in students with Abitur-holding parents attending Gymnasium when compared to students whose parents are not.

It appears that highly educated families reacted to improved opportunities and made use of their resources in a way that is potentially impossible for other families. Nevertheless, for children of both parents with and without the Abitur, participation rates in Gymnasium became remarkably similar in East and West Germany postreunification. Notably, since reunification, there has been a considerable increase in Gymnasium participation in East Germany among students whose parents are not Abitur holders. While IEO in East Germany increased, the outlook for students who do not have Abitur-holding parents improved as the likelihood of attaining the Abitur increased for both groups.

The finding of convergence of IEO between East and West Germany is more compatible with the idea that East Germany's institutional adaptation of the West German tracked education system was the main driver of this change. Aside from outlier Mecklenburg-Vorpommern, the Länder-level analysis provides further evidence of convergence. The prolonged duration of IEO equalization to West German levels in Sachsen and Thüringen compared to Brandenburg and SachsenAnhalt may be attributed to the fact that teachers in Sachsen and Thüringen had the decision-making power over whether a student should attend Gymnasium instead of parents. Nevertheless, in all Länder, students with Abitur-holding parents profited more substantially from these institutional changes than students whose parents are not. Although this does not exclude the possibility that the economic recession postreunification contributed to an increasing level of IEO, the striking similarity in IEO levels between East and West Germany makes the institutional adaptation mechanism more plausible. This is also in line with findings that IEO increased most in those Central and Eastern European countries that followed the West German example and reinstalled early school tracking (Kogan, Gebel, and Noelke 2012).

This study makes significant contributions to research on IEO by investigating the role of institutional and economic changes in shaping socially stratified educa- 
tional pathways. Firstly, we showed that a socialist system, such as the GDR, did indeed have lower levels of IEO than a free-market economy. However, it was not able to eradicate IEO through policies explicitly aimed to support working-class children and an institutional system incorporating low and late tracking. That the political and institutional setting of the GDR did not promote higher levels of Abitur attainment among students whose parents are not Abitur holders is a striking result of our analysis. Instead, the GDR's lower level of IEO was achieved by suppressing the number of students from highly educated backgrounds who would, without the restrictions created by the political system, have exploited family resources. This policy achieved lower overall Abitur rates compared to in a free-market system. Also, children with lower-educated parents had a higher probability of attaining the Abitur in the FRG compared to in the GDR for cohorts born from the 1950s onward.

Secondly, our results showed that IEO in East Germany increased after reunification and adapted to the West German level. This result is in line with research on other transition states that consistently found increasing social inequalities posttransition (Beblo and Lauer 2004; Bukodi and Goldthorpe 2010; Gerber 2000; Hazans, Trapeznikova, and Rastrigina 2008; Hertz, Meurs, and Selcuk 2009; Mateju, Rehakova, and Simonova 2003; Varga 2006). Compared to previous studies, our study is advantageous in comparing the development of IEO in East Germany with the level of IEO in a country from which it adopted the institutional features of education and the labor market. We attribute the emergence of striking similarity of IEO in both parts of Germany across reunification to the east's institutional adaptation of the West German education system. Students with highly educated parents benefited disproportionately from the expansion of secondary education and the changes in the educational decision-making process and tracking age when compared to students with less-educated parents. Our results therefore suggest that educational reforms, which are concerned with the extent and timing of tracking and parental freedom of educational decision-making, are consequential for the level of IEO in modern societies.

Our analysis only looks at changes in social inequalities in Abitur attainment across time in both parts of Germany. For West Germany, we found a declining relationship between parents' education and Abitur attainment across cohorts. This is, however, only one part of the picture of IEO because social inequalities in entering higher education were found to increase over time in West Germany (Müller and Pollak 2016; Schindler and Lörz 2012). Although Abitur attainment was almost equivalent to entering higher education in the GDR, the education system after reunification also offered new flexibility for post-Abitur pathways. Future research may therefore be concerned with comparing East and West Germany in the levels of social inequality at the transition to university. Given that the focus of this article was IEO, we were not able to analyze intergenerational social mobility patterns. Due to potential differences between East and West Germany in labormarket returns to Abitur, comparing the association between social origin and labor-market destination before and after reunification may yield different results. To gain a comprehensive picture of changes in inequality of opportunity, future research may thus study the level of intergenerational social reproduction in East and West Germany before and after reunification. 


\section{Notes}

1 The percentage of students attending Gesamtschulen is small but has slightly increased over time (Becker 2017).

2 To make the selection procedure more inclusive, the SED extended the definition of "worker" so that it included nearly everyone.

3 Around 95 percent of 18-year-olds lived with their parents in GMC data (Klein et al. 2010).

4 In both surveys, individuals provided their information on the Abitur attainment retrospectively and may therefore have attained their Abitur not during initial education. This could be problematic, as some of the last cohorts entered secondary education under the GDR but may have achieved their Abitur postreunification. To limit incidences of delayed Abitur attainment, Figure A1 in the online supplement shows the GGSS results when restricting the sample to individuals aged 30 or younger at the time of the interview. The results are broadly consistent with Figure 4. Our additional analysis suggests no evidence that our trends are due to delayed Abitur attainment after reunification.

\section{References}

Barone, Carlo, Antonio Schizzerotto, Giovanni Abbiati, and Gianluca Argentin. 2017. “Information Barriers, Social Inequality, and Plans for Higher Education: Evidence from a Field Experiment." European Sociological Review 33:84-96. https://doi .org/10.1093/ esr/jcw050.

Baske, Siegfried. 1990. “Die Erweiterte Oberschule in Der DDR.” Pp. 210-7 in Vergleich von Bildung und Erziehung in der Bundesrepublik Deutschland und in der Deutschen Demokratischen Republik, edited by O. Anweiler. Köln. Cologne, Germany: Verlag Wissenschaft und Politik.

Beblo, Miriam, and Charlotte Lauer. 2004. “Do Family Resources Matter? Educational Attainment during Transition in Poland." Economics of Transition 12:537-58. https: //doi.org/10.1111/j.0967-0750.2004.00192.x.

Becker, Rolf. 2017. "Entstehung Und Reproduktion Dauerhafter Bildungsungleichheiten." Pp. 89-150 in Lehrbuch der Bildungssoziologie. 3rd ed., edited by R. Becker. Wiesbaden, Germany: Springer VS.

Berger, Joel, and Benita Combet. 2017. "Late School Tracking, Less Class Bias in Educational Decision-Making? The Uncertainty Reduction Mechanism and Its Experimental Testing." European Sociological Review 33:124-36. https://doi.org/10.1093/esr/jcw054.

Blossfeld, Hans-Peter. 1993. "Changes in Educational Opportunities in the Federal Republic of Germany: A Longitudinal Study of Cohorts Born Between 1916 and 1965." Pp. 51-74 in Persistent Inequality: Changing Educational Attainment in Thirteen Countries, edited by Y. Shavit and H. P. Blossfeld. Boulder, CO: Westview Press.

Blossfeld, Hans-Peter, and Yossi Shavit. 1993. Persistent Inequality: Changing Educational Attainment in Thirteen Countries. Boulder, CO: Westview Press.

Bol, Thijs, Jacqueline Witschge, Herman G. van de Werfhorst, and Jaap Dronkers. 2014. "Curricular Tracking and Central Examinations: Counterbalancing the Impact of Social Background on Student Achievement in 36 Countries." Social Forces 94:1545-72. https : //doi.org/10.1093/sf/sou003. 
Breen, Richard, Ruud Luijkx, Walter Müller, and Reinhard Pollak. 2009. "Nonpersistent Inequality in Educational Attainment: Evidence from Eight European Countries." American Journal of Sociology 114:1475-521. https ://doi .org/10.1086/595951.

Brock, Angela. 2009. "Producing the 'Socialist Personality'? Socialisation, Education, and the Emergence of New Patterns of Behaviour." Pp. 220-50 in Power and Society in the GDR, 1961-1979. The "Normalisation of Rule"?, edited by M. Fulbrook. Oxford, United Kingdom: Berghahn Books.

Brunello, Giorgio, and Daniele Checchi. 2007. “Does School Tracking Affect Equality of Opportunity? New International Evidence." Economic Policy 22:781-861. https : //doi.org/10.1111/j.1468-0327.2007.00189.x.

Bukodi, Erzsébet, and John H. Goldthorpe. 2010. "Market versus Meritocracy: Hungary As a Critical Case." European Sociological Review 26:655-74. https://doi .org/10.1093/esr/ jcp043.

Diewald, Martin, Heike Solga, and Anne Goedicke. 2002. “Back to Labour Markets Who Got Ahead in Post-Communist Societies after 1989?" European Societies 4:27-52. https://doi .org/10.1080/14616690220130982.

Dollmann, Jörg. 2016. “Less Choice, Less Inequality? A Natural Experiment on Social and Ethnic Differences in Educational Decision-Making." European Sociological Review 32:203-15. https://doi.org/10.1093/esr/jcv082.

Ehlert, Martin, Claudia Finger, Alessandra Rusconi, and Heike Solga. 2017. “Applying to College: Do Information Deficits Lower the Likelihood of College-Eligible Students from Less-Privileged Families to Pursue Their College Intentions?: Evidence from a Field Experiment." Social Science Research 67: 193-212. https://doi.org/10.1016/j . ssresearch.2017.04.005.

Erikson, Robert. 1996. "Explaining Change in Educational Inequality - Economic Security and School Reforms." Pp. 95-112 in Can Education Be Equalized? The Swedish Case in Comparative Perspective, edited by R. Erikson and J. O. Jonsson. Boulder, CO: Westview Press.

Erikson, Robert, and Jan O. Jonsson. 1996. “Explaining Class Inequality in Education: The Swedish Test Case." Pp. 1-63 in Can Education Be Equalized? The Swedish Case in Comparative Perspective, edited by R. Erikson and J. O. Jonsson. Boulder, CO: Westview Press.

Fischer, Andreas. 1992. Das Bildungssystem Der DDR. Entwicklung, Umbruch Und Neugestaltung Seit 1989. Darmstadt, Germany: Wissenschaftliche Buchgesellschaft.

Freitag, Markus, and Raphaela Schlicht. 2009. "Educational Federalism in Germany: Foundations of Social Inequality in Education." Governance: An International Journal of Policy, Administration, and Institutions 22:47-72. https : //doi .org/10.1111/ j .1468-0491.2008. 01421.x.

Frick, Joachim R., Richard Hauser, Klaus Müller, and Gert G. Wagner. 1995. “Income Distribution in East Germany in the First Five Years after the Fall of the Wall." MOST: Economic Policy in Transitional Economies 5:79-108. https://doi .org/10.1007/BF00996596.

Fuller, Linda. 1999. Where Was the Working Class?: Revolution in Eastern Germany. Chicago, IL: University of Illinois Press.

Gebel, Michael. 2011. "Hard Times for the Less Educated: Education and Labor Market Entry in East Germany after Reunification." Pp. 58-84 in Making the Transition: Education and Labor Market Entry in Central and Eastern Europe, edited by I. Kogan, C. Noelke, and M. Gebel. Stanford, CA: Stanford University Press. 
Gerber, Theodore P. 2000. "Educational Stratification in Contemporary Russia: Stability and Change in the Face of Economic and Institutional Crisis." Sociology of Education 73:219-46. https://doi.org/10.2307/2673232.

GESIS Leibniz Institute for the Social Sciences. 2016. “ZA4582: ALLBUS/GGSS 1980-2014 (Kumulierte Allgemeine Bevölkerungsumfrage der Sozialwissenschaften/Cumulated German General Social Survey 1980-2014)." Retrieved July 17, 2017 (https : //dbk . gesis . org/dbksearch/sdesc2 . asp?no=4582\&db=e\&doi=10.4232/1.12646).

GESIS Leibniz Institute for the Social Sciences. 2017. “ZA5250: ALLBUS/GGSS 2016 (Allgemeine Bevölkerungsumfrage der Sozialwissenschaften/German General Social Survey 2016)." Retrieved November 29, 2017 (https : //dbk.gesis.org/dbksearch/sdesc2. asp?no=5250\&db=e\&doi=10.4232/1.12796).

Goedicke, Anne. 2006. "A 'Ready-Made State': The Mode of Institutional Transition in East Germany after 1989." Pp. 44-64 in After the Fall of the Wall: Life Courses in the Transformation of East Germany, edited by M. Diewald, A. Goedicke and K. U. Mayer. Stanford, CA: Stanford University Press.

Grünert, Holle, Burkart Lutz, and Ingo Wiekert. 2006. Zukunftsperspektiven der Berufsausbildung in den Neuen Ländern und die Rolle der Bildungsträger. Halle, Germany: Zentralinstitut für Sozialforschung Halle.

Hadjar, Andreas, and Joël Berger. 2010. "Dauerhafte Bildungsungleichheiten in Westdeutschland, Ostdeutschland Und Der Schweiz." Zeitschrift Für Soziologie 39:182-201. https://doi.org/10.1515/zfsoz-2010-0302.

Hanushek, Eric A., and Ludger Wößmann. 2006. “Does Educational Tracking Affect Performance and Inequality? Differences-in-Differences Evidence Across Countries." The Economic Journal 116:C63-76. https://doi .org/10.1111/j .1468-0297.2006.01076.x.

Hazans, Mihails, Ija Trapeznikova, and Olga Rastrigina. 2008. "Ethnic and Parental Effects on Schooling Outcomes before and during the Transition: Evidence from the Baltic Countries." Journal of Population Economics 21:719-49. https ://doi .org/10.1007/ s00148-007-0134-y.

Headey, Bruce, Rudolph Andorka, and Peter Krause. 1995. "Political Legitimacy versus Economic Imperatives in System Transformation: Hungary and East Germany 1990-93." Social Indicators Research 36:247-73. https : //doi .org/10.1007/BF01078816.

Heine, Christoph, Heike Spangenberg, and Markus Lörz. 2007. “Nachschulische Werdegänge Studienberechtigter Schulabgänger/innen. Zweite Befragung der Studienberechtigten $20023 \frac{1}{2}$ Jahre nach Schulabgang im Zeitvergleich." HIS: Forum Hochschule 11/2007. Retrieved May 21, 2016 (http://www.gbv.de/dms/zbw/550208658.pdf).

Heineck, Guido, and Regina T. Riphahn. 2009. "Intergenerational Transmission of Educational Attainment in Germany: The Last Five Decades." Jahrbücher Für Nationalökonomie Und Statistik 229:36-60. https : //doi .org/10.1515/jbnst-2009-0104.

Helbig, Marcel, and Rita Nikolai. 2015. Die Unvergleichbaren. Der Wandel der Schulsysteme in den Deutschen Bundesländern seit 1949. Bad Heilbrunn, Germany: Klinkhardt.

Henz, Ursula, and Ineke Maas. 1995. “Chancengleichheit durch die Bildungsexpansion?" Kölner Zeitschrift Für Soziologie Und Sozialpsychologie 47:605-33.

Hertz, Tom, Mieke Meurs, and Sibel Selcuk. 2009. “The Decline in Intergenerational Mobility in Post-Socialism: Evidence from the Bulgarian Case." World Development 37:739-52. https://doi.org/10.1016/j.worlddev.2008.07.006.

Hillmert, Steffen, and Marita Jacob. 2010. "Selections and Social Selectivity on the Academic Track: A Life-Course Analysis of Educational Attainment in Germany." Research in Social Stratification and Mobility 28:59-76. https : //doi .org/10.1016/j .rssm.2009.12.006. 
Jackson, Michelle, and Geoffrey Evans. 2017. "Rebuilding Walls: Market Transition and Social Mobility in the Post-Socialist Societies of Europe." Sociological Science 4:54-79. https://doi.org/10.15195/v4.a3.

Jackson, Michelle, and Jan O. Jonsson. 2013. "Why Does Inequality of Educational Opportunity Vary Across Countries? Primary and Secondary Effects in Comparative Context." Pp. 306-38 in Determined to Succeed?: Performance versus Choice in Educational Attainment, edited by M. Jackson. Stanford, CA: Stanford University Press.

Jonsson, Jan O., Colin Mills, and Walter Müller. 1996. “A Half Century of Increasing Educational Openness? Social Class, Gender and Educational Attainment in Sweden, Germany and Britain." Pp. 183-206 in Can Education Be Equalized? The Swedish Case in Comparative Perspective, edited by R. Erikson and J. O. Jonsson. Boulder, CO: Westview Press.

Kerr, Clark, John T. Dunlop, Frederick H. Harbison, and Carles A. Myers. 1973. Industrialism and Industrial Man. 2nd ed. Cambridge, MA: Harvard University Press.

Kesler, Christel. 2003. "Educational Stratification and Social Change: Evidence from German Unification." European Sociological Review 19:467-82. https ://doi .org/10.1093/esr/19. 5.467.

Klein, Markus, Steffen Schindler, Reinhard Pollak, and Walter Müller. 2010. "Soziale Disparitäten in der Sekundarstufe und ihre Langfristige Entwicklung." Zeitschrift Für Erziehungswissenschaft 12:47-73. https://doi .org/10.1007/978-3-531-92216-4_3.

Kogan, Irena, Michael Gebel, and Clemens Noelke. 2012. "Educational Systems and Inequalities in Educational Attainment in Central and Eastern European Countries." Studies of Transition States and Societies 4:69-83.

Köller, Olaf, Rainer Watermann, and Ulrich Trautwein. 2004. “Transformation des Sekundarschulsystems in der Bundesrepublik Deutschland: Differenzierung, Öffnung von Bildungswegen und die Wahrung von Standards." Pp. 13-28 in Wege zur Hochschulreife in Baden-Württemberg. TOSCA - Eine Untersuchung an Allgemeinbildenden und Beruflichen Gymnasien, edited by O. Köller, R. Watermann, U. Trautwein, and O. Lüdtke. Opladen, Germany: Leske und Budrich.

Lavrijsen, Jeroen, and Ides Nicaise. 2016. “Educational Tracking, Inequality and Performance: New Evidence from a Differences-in-Differences Technique." Research in Comparative and International Education 11:334-49. https ://doi.org/10.1177/1745499916664818.

Mateju, Petr, Blanka Rehakova, and Natalie Simonova. 2003. "Transition to University under Communism and after Its Demise. The Role of Socio-economic Background in the Transition Between Secondary and Tertiary Education in the Czech Republic 1948-1998." Czech Sociological Review 39:301-24.

Mayer, Karl Ulrich. 1995a. “ZA2645: Courses of Life and Social Change: Courses of Life and Welfare Development (Life History Study LV-West I)." GESIS Data Archive. Retrieved October 30, 2014 (http: //dx . doi .org/10.4232/1.2645).

Mayer, Karl Ulrich. 1995b. "ZA2648: Courses of Life and Social Change: Access to Occupation in Employment Crisis (Life History Study LV-West III)." GESIS Data Archive. Retrieved October 30, 2014 (http://dx. doi.org/10.4232/1.2648).

Mayer, Karl Ulrich. 1995c. "ZA2644: Courses of Life and Historical Change in East Germany (Life History Study LV DDR)." GESIS Data Archive. Retrieved October 30, 2014 (http: //dx.doi.org/10.4232/1.2644).

Mayer, Karl Ulrich. 2004. "ZA3926: East German Life Courses after Unification (Life History Study LV Ost 71)." GESIS Data Archive. Retrieved October 30, 2014 (http: //dx.doi.org/10.4232/1.3926). 
Mayer, Karl Ulrich. 2008. "Retrospective Longitudinal Research: The German Life History Study." Pp. 85-106 in Handbook of Longitudinal Research: Design, Measurement and Analysis, edited by S. Menard. San Diego, CA: Elsevier.

Mayer, Karl Ulrich, and Gerhard Kleinhenz. 2004. “ZA3927: Education, Training, and Occupation: Life Courses of the 1964 and 1971 Birth Cohorts in West Germany (Life History Study LV-West 64/71)." GESIS Data Archive. Retrieved October 30, 2014 (http: //dx.doi.org/10.4232/1.3927).

McPherson, Andrew, and J. Douglas Willms. 1987. “Equalisation and Improvement: Some Effects of Comprehensive Reorganisation in Scotland." Sociology 21:509-39. https: //doi.org/10.1177/0038038587021004003.

Meulemann, Heiner. 1992. “Expansion ohne Folgen? Bildungschancen und Sozialer Wandel in der Bundesrepublik." Pp. 123-56 in Entwicklungstendenzen der Sozialstruktur, edited by W. Glatzer. Frankfurt, Germany: Campus.

Mickler, Otfried, Norbert Engelhard, Ralph Lungwitz, and Bettina Walker. 1996. Nach der Trabi-Ära: Arbeiten in Schlanken Fabriken. Modernisierung der Ostdeutschen Autoindustrie. Berlin, Germany: Edition Sigma.

Micklewright, John, Mark Pearson, and Stephen Smith. 1990. “Unemployment And Early School Leaving." Economic Journal 100:163-9. https://doi .org/10.2307/2234193.

Müller, Walter, and Dieter Haun. 1994. "Bildungsungleichheit im Sozialen Wandel." Kölner Zeitschrift für Soziologie Und Sozialpsychologie 46:1-42. https://doi .org/10.1007/ 978-3-322-80354-2_14.

Müller, Walter, and Reinhard Pollak. 2016. “Weshalb Gibt es so Wenige Arbeiterkinder an Deutschlands Universitäten?" Pp. 345-86 in Bildung als Privileg: Erklärungen und Befunde $z$ u den Ursachen der Bildungsungleichheit. 5th ed., edited by R. Becker and W. Lauterbach. Wiesbaden, Germany: Springer VS.

Müller, Walter, and Wolfgang Karle. 1993. "Social Selection in Educational Systems in Europe." European Sociological Review 9:1-22. https://doi .org/10.1093/oxfordjournals . esr.a036652.

Müller, Walter, Susanne Steinmann, and Renate Ell. 1998. "Education and Labour-Market Entry in Germany." Pp. 143-88 in From School to Work: A Comparative Study of Educational Qualifications and Occupational Destinations., edited by Y. Shavit and W. Müller. Oxford, United Kingdom: Clarendon Press.

Pfeffer, Fabian T. 2008. "Persistent Inequality in Educational Attainment and Its Institutional Context." European Sociological Review 24:543-65. https://doi .org/10.1093/esr/ jen026.

Pfeffer, Fabian T. 2015. “Equality and Quality in Education. A Comparative Study of 19 Countries." Social Science Research 51:350-68.

Raffe, David, and J. Douglas Willms. 1989. "Schooling the Discouraged Worker: LocalLabour-Market Effects on Educational Participation." Sociology 23:559-81. https ://doi . org/10.1177/0038038589023004004.

Riphahn, Regina T., and Parvati Trübswetter. 2011. “The Intergenerational Transmission of Educational Attainment in East and West Germany." IAB Discussion Paper 4:1-35.

Schimpl-Neimanns, Bernhard. 2000. "Soziale Herkunft und Bildungsbeteiligung. Empirische Analysen zu Herkunftsspezifischen Bildungsungleichheiten Zwischen 1950 Und 1989." Kölner Zeitschrift für Soziologie Und Sozialpsychologie 52:636-69. https://doi.org/10 . 1007/s11577-000-0102-y.

Schindler, Steffen. 2014. Wege zur Studienberechtigung - Wege ins Studium? Eine Analyse Sozialer Inklusions- und Ablenkungsprozesse. Wiesbaden, Germany: Springer VS. 
Schindler, Steffen, and Markus Lörz. 2012. "Mechanisms of Social Inequality Development: Primary and Secondary Effects in the Transition to Tertiary Education Between 1976 and 2005." European Sociological Review 28:647-60. https://doi .org/10.1093/esr/jcr032.

Schneider, Thorsten. 2008. "Social Inequality in Educational Participation in the German School System in a Longitudinal Perspective: Pathways into and out of the Most Prestigious School Track." European Sociological Review 24:511-26. https://doi .org/10.1093/ esr/jen017.

Schütz, Gabriela, Heinrich Ursprung, and Ludger Wößmann. 2008. “Education Policy and Equality of Opportunity." Kyklos 61:279-308. https : //doi . org/10.1111/j.1467-6435. 2008.00402.x.

Sieben, Inge, Johannes Huinink, and Paul M. De Graaf. 2001. “Family Background and Sibling Resemblance in Educational Attainment." European Sociological Review 17:401-30. https://doi.org/10.1093/esr/17.4.401.

Treiman, Donald J. 1970. "Industrialization and Social Stratification." Pp. 207-34 in Social Stratification Research and Theory for the 1970s, edited by E. O. Laumann. Indianapolis, IN: Bobbs-Merrill. https://doi.org/10.1111/j.1475-682X.1970.tb01009.x.

Troltsch, Klaus, Günter Walden, and Susanne Zopf. 2009. “Im Osten Nichts Neues? 20 Jahre nach dem Mauerfall Steht die Berufsausbildung vor Großen Herausforderungen." BIBB Report 12:1-14.

van de Werfhorst, Herman G., and Jonathan J. B. Mijs. 2010. “Achievement Inequality and the Institutional Structure of Educational Systems: A Comparative Perspective." Annual Revue of Sociology 36:407-28. https : //doi . org/10.1146/annurev . soc. 012809.102538.

Varga, Julia. 2006. "The Role of Labour Market Expectations and Admission Probabilities in Students' Application Decisions on Higher Education: The Case of Hungary." Education Economics 14:309-27. https://doi.org/10.1080/09645290600777535.

von Below, Susanne. 2017. "Bildungssysteme im Historischen und Internationalen Vergleich." Pp. 151-78 in Lehrbuch der Bildungssoziologie. 3rd ed., edited by R. Becker. Wiesbaden, Germany: Springer VS. https ://doi .org/10.1007/978-3-658-15272-7_5.

von Below, Susanne, Justin J. W. Powell, and Lance W. Roberts. 2013. “Educational Systems and Rising Inequality: Eastern Germany after Unification." Sociology of Education 86:36275. https://doi.org/10.1177/0038040713496585.

Winkler, Oliver. 2017. Aufstiege und Abstiege im Bildungsverlauf: Eine Empirische Untersuchung zur Öffnung von Bildungswegen. Wiesbaden, Germany: Springer VS. https : //doi .org/ 10.1007/978-3-658-15726-5.

Wolbers, Maarten H. J., Paul M. De Graaf, and Wout C. Ultee. 2001. “Trends in the Occupational Returns to Educational Credentials in the Dutch Labor Market: Changes in Structures and in the Association?" Acta Sociologica 44:5-19. https://doi .org/10.1177/ 000169930104400102. 
Acknowledgments: The authors gratefully acknowledge the participants in the German Life History Study (GLHS), the German General Social Survey (GGSS), and the German Microcensus (GMC) for providing their information; the Max Planck Institute for Human Development in Berlin for collecting and managing the GLHS data; the GESIS Leibniz Institute for the Social Sciences for collecting and managing the GGSS data; and the statistical offices of the Länder under the supervision of the Federal Statistical Office for collecting and managing the GMC data. The authors would also like to thank Walter Müller, Andreas Hadjar, and Ian Rivers for their valuable comments on an earlier draft of the manuscript; Julia Däumling for the excellent research assistance; and Matilda Klein for the copyediting. Sole responsibility for any remaining errors lies with the authors.

Markus Klein: School of Education, University of Strathclyde.

E-mail: markus.klein@strath.ac.uk.

Katherin Barg: Graduate School of Education, University of Exeter.

E-mail: k.barg@exeter.ac.uk.

Michael Kühhirt: Institute of Sociology and Social Psychology, University of Cologne.

E-mail: michael.kuehhirt@uni-koeln.de. 